УДк 73.01

\author{
Karpov Victor, \\ Doctor of Historical sciEnces, Head of Department \\ of Art Study Expertise at the National \\ Academy of Managerial Staff of Culture and Arts \\ vvkarpoff@ukr.net \\ ORCID 0000-0002-3446-9187
}

\title{
EXAMINATION OF WORKS OF ART IN THE CHRONOTOP OF CULTURE: ASPECTS OF PROFESSIONAL TRAINING OF SPECIALISTS
}

The purpose of the study is to highlight the essence of the process of preparation of art experts initiated in the independent Ukraine. Research methods. The choice of research strategies in disclosing the purpose of the study determined the application of system and complex approaches, as well as historical-chronological and comparative methods. The scientific novelty of the obtained results consists in the formulation and development of an actual topic, which in scientific terms did not receive comprehensive and objective coverage and is first investigated. The results of comprehension of the essence of the process of preparation of expert art experts can serve as an important component in the study of contemporary issues of artistic education. Conclusions. The development of the socio-cultural space of Ukraine has revealed the objective need to expand the range of work aimed at preserving and protecting cultural heritage. The distinction in this sector of the culture of the problem of training specialists with the expertise of experts is a natural phenomenon. It was emphasized that such training is being conducted at the National Academy of Culture and Arts Management.

Key words: art expert, expert, training specialists, cultural heritage, National Academy of Culture and Arts Management.

Карпов Віктор Васильович, доктор історичних наук, завідувач кафредри мистецтвознавчої експертизи Національної академії керівних кадрів культури і мистецтв

Експертиза творів мистецтва у хронотопі культури: аспекти професійної підготовки фахівців

Мета дослідження полягає у висвітленні сутності започаткованого в незалежній Україні процесу підготовки мистецтвознавців-експертів. Методи дослідження. Вибір дослідницьких стратегій у розкритті мети дослідження визначив застосування системного та комплексного підходів, а також історико-хронологічного та порівняльного методів. Використання вказаних методів дослідження сприяло отриманню власних результатів. Наукова новизна одержаних результатів полягає у постановці і розробці актуальної теми, яка в науковому вимірі не отримала всебічного й об'єктивного висвітлення та досліджується вперше. Результати осмислення сутності процесу підготовки мистецтвознавців-експертів можуть слугувати важливою складовою у дослідженні сучасних проблем мистецької освіти. Висновки. Розвиток соціокультурного простору України виявив об'єктивну необхідність розширення спектру роботи спрямованої на збереження та охорону культурної спадщини. Виокремлення у цьому секторі культури проблеми підготовки фахівців із компетентностями експертів $є$ закономірним явищем. Підкреслено, що така підготовка проводиться у Національній академії керівних кадрів культури і мистецтв.

Ключові слова: мистецтвознавець, експерт, пілготовка спеціалістів, кафедра, культурна спадщина, Національна академія керівних кадрів культури і мистецтв.

Карпов Виктор Васильевич, доктор исторических наук, заведующий кафредрой искусствоведческой экспертизы Национальной академии руководящих кадров культуры и искусств

Экспертиза произведений искусства в хронотопе культуры: аспекты профессиональной подготовки специалистов

Цель исследования заключается в освещении сущности начатого в независимой Украине процесса подготовки искусствоведов-экспертов. Методы исследования. Выбор исследовательских стратегий в раскрытии цели исследования определил применение системного и комплексного подходов, а также историко-хронологического и сравнительного методов. Использование указанных методов исследования способствовало получению собственных результатов. Научная новизна исследования заключается в постановке и разработке актуальной темы, которая в научном измерении не получила всестороннего и объективного освещения и исследуется впервые. Результаты осмысления сущности процесса подготовки искусствоведов-экспертов могут служить важной составляющей в исследовании современных проблем художественного образования. Выводы. Развитие социокультурного пространства Украины обнаружил объективную необходимость расширения спектра работы направленной на сохранение и охране культурного наследия. Выделение в этом секторе культуры проблемы подготовки специалистов по компетенциями экспертов является закономерным явлением. Подчеркнуто, что такая подготовка проводится в Национальной академии руководящих кадров культуры и искусств.

Ключевые слова: искусствовед, эксперт, пилготовка специалистов, кафедра, культурное наследие, Национальная академия руководящих кадров культуры и искусств.

The development of the socio-cultural space of Ukraine in the entry period of independence was marked by the stagnation of cultural practices which were adopted during the Soviet period and the emergence of the new ones. In particular, we are talking about the collection of cultural values and objects of art. This process took place in the Soviet era, but it was affected by the dominant position of state museums. The role of public institutions faded away, and private initiative appeared dominant for various reasons during the period of social transgression. There was not only a layer of collectors, but also traders and dealers, who formed the private market for the movement of collectibles. This market rapidly acquired mature forms quickly and went beyond the borders of the country, became an element of the international market system of cultural values trade.

However, governments in the field of culture did not notice the significance of the mentioned process immediately and the need to carry out training in this area. The case at the customs border which occurred with a representative of the diplomatic corps of one of the European countries was typical and led ultimately to the support of the initiative of specialists to introduce the training of art critics with a specialization of the art market expert. The diplomat exported a copy of Rodin's sculpture from Ukraine to complete the own collection. The incident had to be pacified at the highest level by the President of Ukraine at that time - L. D. Kuchma. The case showed the absence 
of a precise mechanism for controlling the border crossing, but also the lack of an adequate number of specialists in the field of culture and art, in particular in the area of art expertise.

Rector of the State Academy of Culture and Arts Management (since 2010 - National), Professor V.G. Chernets criticized this diplomatic incident and supported the initiative of specialists and the public in training specialists in the field of cultural values expertise by the academy. The department of art history and expert activities was established for the preparation of the art experts by the decision of the Academic Council of the Academy in 2001.

The formation of the department of art expertise occurred during the main shaping processes of the independent Ukrainian state. The lecturers of the department borrowed the experience of teaching the history of the fine arts in the leading departments of higher educational institutions of the country and added author's educational and methodological developments in the field of examination and evaluation of cultural values, which became a central feature of the department and distinguishes it from other art history and museum departments.

The creation of the department provided for the training of art historians and experts with the skills of materials research, appraisers, auction and gallery art specialists as well as specialists, who comprehensively master the basics of working with works of art, collectibles, and archaeological finds.

The first meeting of the faculty of the department was held on September 5, 2001, which can be considered the Day of the department, chaired by the head of the department of art history and expert activities - the famous Ukrainian art historian, doctor of art history, honored cultural worker of Poland, academician of the Academy of Arts of Ukraine, specialist in the field of cultural values mobility - Professor Fedoruk O.K. The department consisted of 12 lecturers. The department was attended by lecturers Belyavina N.D., Tereshchenko A.K., Vrublevsky V.B., Ulanova S.I., Papeta S.P., Romashchenko V.N., Kovalchuk A.V., Suprun A.T. and the head of the laboratory of the department Abbakumov V.A. as a minute taker. The first issue on the agenda of the department meeting was considered "the task of the educational process of the department of art history and expert activities for the 20012002 academic year" $[1,1]$.

Head of the Department Fedoruk O.K. introduced each lecturer and staff member of the department. He noted that the department is newly formed and was allocated in a separate independent department only in early September. Thus, the training of specialists in the specialty "art expert" and "musicologist expert" was carried out within the framework of the tasks of the theory, history, and practice of culture department. Fedoruk O.K. noted an exceptional faculty of the new department, which consists of 3 professors, 3 associate professors as well as lecturers, who have extensive practical experience and are well-known experts in the field of art history and musicology.

The head of the department referred the provision of a high scientific and professional level of teaching the art disciplines, adherence to the primary strategy of educational and teaching activities, providing students with the necessary literature to the central issues of the educational process of the department for the 2001-2002 academic year. Fedoruk O.K. outlined the main activities of the department in the framework of the academy concept. These areas were educational work, organizational and methodological work, scientific work and social events.

Lecturers of the department attended the discussion. In particular, deputy head of the department, dean of the faculty of art Belyavina N.D. noticed that taking into account the fact that the department is new, it is necessary to start "from scratch." She noted that from the Department of Theory, History, and Practice of Culture, "we took several programs that were developed in that year" [1,2]. The task of the department and each lecturer was to develop educational and methodological complexes for each discipline, to improve the content of educational and thematic plans, and to provide methodological support to the educational process.

An essential task for the newly created department at the entry stage of work was preparation for the accreditation of a specialty which included, first of all, the training modules development. In October 2001, at the session of the department, the plan for the preparation of curricula was reviewed and approved. This month the faculty was expanded by new lecturers - Menzhulin O.I., Tkachenko N.M., Balakina M.M., Mal'kov S.V., Bondarenko M.I. and Vakulenko Y.E. In January 2002 Cherkassky L.M. and Revenok N.M. joined the faculty staff. Thus, the team of the department was represented by experts in art criticism, restoration as well as cultural and museum practices.

General subjects of educational disciplines were worked out, which included the following: instrumental study (Belyavina N.D.); the history of foreign art (Papeta S.P.); the history of ancient art (Papeta S.P.); material science (Balakina M.M.); the history of decorative arts (Mingzhulin O.I.); the history of musical art (Tereschenko A.K.); the basis of the national policy of preserving the historical and cultural heritage (Vrublevskaya V.B.); examination of works of arts and crafts (Mingzhulin O.I.); examination of cult attributes (Romashchenko V.M.); examination of works of fine art (Vakulenko Y.E.); basics of restoration of artistic works (Romashchenko V.M.); fundamentals of museology (Vrublevskaya V.B.); research methods and technical means of expertise (Vakulenko Y.E.); specialized art creativity (in December the subject was changed to a new one: "theory of fine art") [1, 12] (Kovalchuk O.V.); the history of fine art for musicologists (Papeta S.P.); examination of wind musical instruments (Mal'kov S.V.); examination of strings of stringed instruments (Belyavina N.D., Ayrov A.I. and Gutsulyak V.D.); research methods and technical means of examination (Bondarenko M.I.); basics of acoustics of musical instruments (Bondarenko M.I.); contemporary musical art (Suprun O.V.); contemporary fine art (Fedoruk O.K.) folklore (Suprun O.V.); analysis of musical works (Ulanov S.I.) $[1,4]$. 


\section{Вісник Національної академії керівних кадрів культури і мистецтв № 2'2019}

The issues of individual plans of lecturers, schedules of mutual interviews, consultations, conducting open lectures, advanced training, approval of curriculum programs were considered at the sessions of the department. It is interesting that at the session of the department there was discussed the development of the material base of the educational process and the creation of a museum for the study of art experts. It was decided to apply to the Academy's administration with a request to allocate a room for the museum and additionally enter the posts of two senior laboratory assistants in the staffing schedule [1, 10], but this idea was not implemented.

In the field of view of the department, there was a question of professional development for lecturers of aesthetic education, musical schools, cultural institutions, restoration institutions, museum workers. In these areas of training, in March 2002, four groups of listeners arrived. Continuous attention was paid to the issue of methodical provision of the educational process - the issues of preparation of the topics of seminars and practical works were discussed with their plans and the provision of literature, control works, themes of course papers and diploma papers, students' independent work, exams, educational and thematic plans for further training, etc.

There was a discussion about the students' choice of diploma and course papers at the department. Fedoruk O.K. noted that the department offered students the selection of the topic, but according to his view, most of the students should choose topics by themselves [1, 22]. According to the lecturer Papet S.P., the students should determine the topics for the diploma research by their interests, and the department should give students the right to choose. The students acted with the initiative to listen to additional topics of lectures and, in particular, some of the subjects of the Judaica were interested.

In June 2002, the lecturers of the department reported about conducting vocational guidance work among the students. In particular, as Malkov S.M. mentions, "we with the associate professor of the department Ivanov L.M. (entered the department in May 2002 - the author's commentary) made a schedule of visits to educational institutions and meetings with applicants. At the meetings, the applicants expressed interest in a new specialization, many questions were asked, on which we gave full answers. "[1, 26] In turn, Papeta S.P. met with antique shop staff, who talked about specialty peculiarities. The result of this work was the recruitment of 12 students with a second higher education to a second course, which began on October 15, 2002.

The department developed the normative base of a new specialty, determined its content and professional orientation of training for the first time in Ukraine. The absence of expert lecturers marked the work of the department, and, therefore, some individual lectures were transferred to subsequent semesters [1, 37].

In August 2002, at the meeting of the department, the question about the creation of an expert laboratory with appropriate equipment and the provision of the premises for this arose again. There were also personnel changes in the department - Revenok N.M. was appointed the secretary of the department and Lysenko-Tkachuk I.V. - the deputy head of the department. The department has a new specialization - choral art and, as Yurchenko M.S. said, "we will start everything from scratch "[1, 30].

The analysis of the first year of the department formation testifies to the superiority of the specialty musicologist-expert, which is explained by the presence of the teaching staff and existing work experience in the field of musical art, and the problematic specialization formation of art expert in the area, of which there were no general developments in educational and methodological literature. The urgent question was the creation of scientific potential of expert activity in the field of art. However, specialization was in demand, which was confirmed by a set of students, and the mentioned fact opened the prospects for the promotion of a specialty.

Through the example of the new specialization - choral art, we note the lack of targeted policy in the development of the specialty at an entry stage. This state of affairs changed in June 2003, when it was decided to supplement the non-essential disciplines to deepen the preparation of art historians and concentrate on the qualifications of an art expert. There was a correction of the names of academic disciplines; as an example, lecturer Vakulenko Y.E. proposed to change the name of the discipline "Methods of research and technical means of examination" to a new one: "Special methods of artworks research." The title of the discipline "Biblical Literature" has been changed to "Iconology." New educational disciplines were introduced to the department's curriculum: "Basics of auctioning," "Fundamentals of scientific research," "Fundamentals of the restoration of artworks." On the proposal of the head of the department, Fedoruk O.K. excluded all disciplines associated with the music profession and included disciplines that had to deepen the training of art experts: "Introduction to Restoration," "Description and Analysis of Art Monuments" and "Museums of the World."

The issue of creating an expert laboratory moved in October 2003 - Fedoruk O.K. said that a laboratory of expertise would significantly improve the educational process and help to demonstrate the methods of examination of artworks to students as well as to facilitate students' acquisition of the skills and abilities envisaged by the program. Veretko N.V. proposed to consider the work plan of the laboratory and the responsibilities of the laboratory manager. On the proposal of Menzhulin O.I., the name of the laboratory was specified as "Laboratory of examination of artworks of the Department of Art and Expertise" [1, 52].

The problem of the development of the material basis of training was constantly relevant - in October 2003, the issue was the acquisition of new computer equipment and the creation of conditions for the assistance of lecturers in the production of teaching aids and auxiliary material for lectures. In April 2004, this issue was on the agenda of the department. In particular, it was noted that lecturers do not have the conditions for the presentation of their lectures, there is no possibility to print documents on the faculty, and teachers prepare their illustrative material at their own expense $[1,77]$. 
At the final session of the department in June 2004, it was noted that the academic year was striking. A number of drawbacks were identified, which should be taken into account when planning the work of the department for the next academic year. Students of the 1st and 2nd years of training generally have successfully passed the credit-exams session. Students of a correspondence form of education expressed the desire to study more professional disciplines.

Compared with last year, the graduates of the 2003-2004 academic year demonstrated solid knowledge of the specialty, from theory, both history of fine arts and expertise. The responses to the state examinations were clear, complete, and engaging. Students worked a lot on the accumulation of material, showed knowledge of the principles and methods of expertise, creative work on the diploma and in-depth understanding of the specialty. The defense of diploma works was held at an appropriately high level under the chairmanship of V. Perevalsky. Works by Leusha M.O., Klevchuk M.M., Kurakov V.M. were recommended for printing due to their high level of performance, innovative approach and in-depth research of unexplored issues [1, 75]. The gold medal for teaching the department was recommended to hand over to Klevchuk M.M. and the silver one to Leusky M.O.

In 2004, in connection with the general preparation of the Academy for accreditation (IV level of higher education), a decision to prepare for the licensing of the magistracy and the opening of the qualification "expert in art, gallery manager and exhibitions" was made. Kuzyanets O.V. was appointed responsible for the preparation of documents for licensing because of his considerable practical experience in this sphere.

Educational and methodical work was carried out, work on the professional orientation of an entrant brought positive results during the enter training campaign. In 2004, 20 students enrolled in the "Fine Arts and Decorative Arts" specialty training course. 2 students entered the second year and 7 students - the third year. 20 students joined the third year and 13 students - the fourth year of the extramural form of study. Total 64 students came to study. Since September 2004, a new stage in the formation of the department and the specialty of art expert-expert have begun. Afanasyev Y. L. become the head of the department. There were personnel changes among the professorial and lecturers staff. The department included Iskvarina K.V., who became the deputy head of the department and Shepa D.V., Oryluk K.V., Romanenko U.V., Rud-Mayevskaya I.A., Bilous L.S. New head noted that the department's available teaching and methodological support for professional disciplines does not take into account changes in curricula that have taken place over the past years, and some disciplines do not have the appropriate software and methodological support. At the same time, Afanasyev Y.L. offered to combine some courses, such as "Examination of subjects and attributes: manuscripts and early printed matter" and "Examination of subjects and attributes: archival documents," as well as some disciplines were removed.

This fact testifies to the constant search for the correspondence of professional disciplines to professional competencies and is the result of the art-expert specialty development.

At the September 2004, the department returned to the question of the work of the educational and creative expert laboratory. The head of the department informed that in connection with the creation of the laboratory, it was necessary to equip it with particular means and reagents. Head of the laboratory Krez V.V. reported on the work which was done and noted that lists had been compiled for the purchase of equipment and materials, but there was a need to work more closely with the lecturers to link the work of the laboratory with the learning process. For successful work, the laboratories decided to instruct all lecturers to prepare the necessary illustrative and laboratory materials, in particular, electronic videos for work on a multimedia projector, object samples of art technologies and materials, and the head of the laboratory determined the list of necessary technical means for ensuring the educational process of the department.

April 2005, the department raised the issue of expanding the material base of the laboratory and proposed the establishment of a Center for the Examination of Cultural Values, to develop its statute and organizational structure. Such a center was formed but not as a part of the department.

The new 2005-2006 academic year was marked by changes in the staffing of the department. On the place of the lecturers, who were retired, the new ones came - Barshynova O.G., Vinogorodskaya L.I., Chernaya L.G., Parkhomenko N.V., Sklyarenko G.Y., Voevodin O.P. Popularity of the art expert specialty marked the admission of the 2005 year. 27 students were recruited on the first course, 12 students on the third year of the extramural form of study, 4 expressed a desire to study on the external form of education.

In this academic year, the lecturer' attention was given to the practical aspects of student training. To improve it, the following practices were introduced in accordance with the courses; for the second course - an educational or museum-studying, which provides acquaintance with the principles of organization of the museum, acquaintance with its exposition, funds, their cataloging, guided tours; for the third year - production with excursion-pedagogical orientation, without leaving the education. The basis of practice was provided by the children's art school of Kyiv. The student had to work out and conduct an excursion on the memorials of Kiev for children. The preparation of such an excursion included the lesson plan and the text of the excursion; for the fourth, there was provided an expert practice with the separation from education.

The beginning of the new 2006-2007 school year was marked by the stability of the personnel potential of the department; its rows were filled by only two new lecturers - Denisyuk O.Y. and Gerasimenko L.P. The beginning of the next academic year did not bring changes in the personnel of the department, which positively influenced the level of teaching and methodological support of the educational process.

The results of the recruitment of students in 2007 showed the interest of entrants in acquiring the profession of the art expert. 16 students were enrolled in the first course of full-time education and 14 ones - the third year of the 
extramural form of study. 2 students have expressed a desire to study on an external form of study. However, the head of the department is Doctor of Philosophy, professor Afanasyev Y..L. noted that the auditorium and material support does not allow a larger number of students $[1,114]$.

18 students of the first year of full-time education and 30 students of the third year of the extramural form of the study were accepted for training in 2008, for the specialty "Fine Arts and Decorative Arts" qualification "artexpert." 15 students of full-time study form and 22 students of the extramural form of the study were accepted for Master's degree for the first time. The material and technical support of the educational process improved - two audiences were equipped with widescreen televisions. Lecturers were given the opportunity to demonstrate in their lectures slides with illustrations of works of art, which improved the quality of teaching. In the updated classrooms, there were delivered opened lectures by Nesterenko P.V. on the topic "Numismatics as a branch historical discipline" and Belichko N.Y. on the theme "Painting of Spain in the XVII century" [1, 180].

The results of admission of students in 2009 indicate a stable popularity of the profession. This year, 14 students of the first year of full-time study and 30 undergraduate students of the extramural form of the study were accepted. 15 students of full-time study form and 19 students of the extramural form of the study were admitted. The staff of the department did not change, and in comparison with last year, it decreased by 4 lecturers. In total, in the 2009-2010 school year, there were 18 lecturers - 5 regular lecturers, 12 part-time and 1 - one-year contract.

On November 26-27, 2009, the Department organized and held the All-Ukrainian Scientific and Practical Conference "Modern Problems of Art Study Expert Evaluation of Cultural Values and Collectibles." The holding of such a conference proved the maturity of the scientific and pedagogical potential of the department, the importance of the methods of expertise for the development of the theory of art criticism and certain recognition of the problems of art criticism in the field of science.

At the same time, the training of Master's degree students revealed the difficulties associated with their employment, which showed the underdevelopment of the labor market in this area. On the other hand, there was a problem of academic disciplines content for the preparation of Master's degree students, which was dictated by the different, inadequate elaboration of the practice of using evaluation techniques in the field of the circulation of art objects and cultural values. As an example, 13 out of 20 third-year students of the ME-86 group wrote a letter refusing the special course "Actual problems of the political history of Ukraine" due to its politicization $[2,8]$.

The 2010-2011 school year was marked by the admission of 27 new students to the first year of study form and 18 for the third year of education, two students enrolled in the second year of full-time undergraduate education, 15 - undergraduate enrollees and 18 full-time students were admitted to the Master's degree. In total - 80 students. The staff of the department did not change - 4 regular lecturers, 12 part-time and 1 - one-year contract.

Since October 2010, the process of preparing art experts has gained new sound. Rector of the Academy Chernets V.G. elected new head of the Department of Art Studies and Expertize was appointed - Professor Sivers V.A., Doctor of Philosophy. The rector noted in the speech that Sivers left the administrative work and went to science by his own initiative. He worked as the head of the department, the dean of the faculty and knows well the educational process. The rector expressed his gratitude to Afanasyev Y.L. for his fruitful work and stressed that during the years of his work on this post the pedagogical staff of the department was formed, the staff of the department was strengthened by experts and practice bases. According to Afanasyev, the department was at the top of its development during the mentioned time [2, 31].

In December 2010, the head of the department consistently held meetings with students of the third year of education and Bachelors. The students expressed a number of suggestions aimed at improving the educational process. In particular, to distribute the load in the semesters and in the courses, reduce the number of disciplines in the humanities and science education, the legal block, increase the number of academic hours of professional training, combine the close-content disciplines, remove courses that repeat the school program, improve the content of the courses concerning expert disciplines and introduce additional ones [2, 41 - 45].

Sivers V.A. suggested creating the Institute of Art and Jewelry Expertize by taking into account the needs of the market, working places in the field of art criticism examination by[3]. Such institute was formed and the department of art criticism and expert activity and the department of jewelry mastery were parts of the mentioned segment. The director of the institute was Professor Sivers V.A., and his deputy on organizational and methodological work was Doctor of Art Studies, Professor Romanenkova U.V. Professor Platonov B.O. became the head of the department of art studies and expert activities since October 2011[2, 101], and professor Romanenkova Y.V. - head of the Department of Jewelry Art. Also, the name of the department was clarified - the direction of valuation activity was supplemented. Within the newly created institute, the concept of the development of the department was corrected and the qualification of Master's degree "art expert, appraiser" was changed to "art expert, gallery and auction specialist."

Lagutenko O.A., Maksimov S.Y., Shkolna O.V., Mikhalevich V.V., Kapustian O.M., Zikeeva S.G., 17 Bachelors of the first year of full-time education and 15 - the extramural form of study joined the department in the 2012-2013 academic year. 18 submitted applications for 3 year of the extramural form of study; 7 full-time students and 17 students of the extramural form of study applied - the total of 77 people. Thus, 169 students studied at the department, 83 of which are full-time students [2, 141].

In 2012, the period of reform continued. From September 2012 the department received the old name - art studies and expert activity [2, 140]. In February 2013, in connection with the reorganization of the Institute of Art Expertize and Jewelry Art, the Department with the name "Department of Applied Art Studies, Art Expertise and 
Jewelry Art" [2, 161] was headed by Doctor of Art Studies, Professor Romanenkova U.V. In April 2013, the restructuring of the Academy and the new subordination of the department took place [2, 163]. However, in September 2013 the department was already named as a department of Jewelry Art [2, 170].

However, in September 2013, the head of the department was appointed experienced practitioner and theoretician in the field of appraisement and expertise of cultural values, Professor V.V. Indutny was appointed the head of the department. He returned its old name - the Department of Art Studies and Expert Activities. The main issues of the Department's work were the restructuring of the academic groups of the first-year full-time and part-time forms of study, which was solved in the working regime $[4,1]$ and the question of the integration of curricula for students of the first year of full-time and part-time study for specialties "Art Expert" "and "Artist of jewelry "[4, 7 - 8].

The 2014-2015 year traditionally began with the session of the Department of Art Study and Expertize, which considered the issues of changes in curricula and approval of lecturers' teaching load. From the minutes of the meeting held on August 28, 2014, we found out, who worked at the department at this time - Indutny V.V., Maksimov S.Y., Mikhalchuk V.V., Morozov A.Y., Platonov O.B., who were regular lecturers. Part-time lecturers were Kravchenko N.I., Kulivnik M.O., Remizovsky I.O., Mikhaylevich V.V., Nesterenko P.V., Petrushevsky A.O., Revenok N.M.; year contracts were concluded with Shataylo Y.M. and Cherkassky L.M. The methodologist of the department was Kryvtsova A.M. [5, 219].

An important milestone of the department's work was the introduction of the latest innovative model of training - the "Art-A" auction in 2013. The auction was organized by students of art historians and students of the Department of Jewelry Art in conjunction with the Center for Ukrainian Culture and Arts under the direction of Dolesko S.V. The funds received from the first auction were aimed at assisting in the treatment of cancer patients. Subsequently, such auctions were held in 2015 and 2018 and acquired a permanent form of training [6].

Rector of the Academy Professor Chernets V.G. reported changes in the leadership of the department in connection with the dismission of Professor Indutny V.V. at the session of the Department on December 12, 2014. Chernets presented the new head - Candidate of Arts, Mazur V.P., who worked on this post until October 2017. The rector emphasized the leading role of the department in the structure of the Academy and expressed concern about the state of its development. According to him, the department is clearly in need of modernization of training specialists in the field of art criticism. He highlighted the improvement of vocational guidance work [5, 190].

In August 2015, a decision to reorganize the Academy's structural subdivisions was made[7], and the department received a new name - the Department of Art Expertise and became a member of the Institute of Art Management and Event Technologies (Director of the Institute Dichkovsky S.I.). At the first meeting of the newly formed department, the results of the student recruitment were summed up. Mazur V.P. reported that "the contingent of students was formed by the results of the competition for submitted papers in the full-time and part-time departments" [5, 162]. In the 2016-2017 academic year, the professors Kuderskaya N.I., Mischenko I.I., Bray N.A., Solarska-Komarchuk I.O., Belichko N.Y. and Timchenko T.R. as part-time lecturers joined the Department. [5, 94].

In 2016, the Department initiated conducting of the international scientific-practical conference "Museums and Restoration in the Context of Preserving the Cultural Heritage: Current Challenges of the Present" in conjunction with the National Kyiv-Pechersk Historical and Cultural Reserve. The mentioned conference has become a permanent form of scientific activity of the Department and is held annually [8].

On November 17, 2016, the traditional meeting of the rector of the Academy Professor Chernets V.G. with the teaching staff of the department took place. The rector expressed hope for the further sustainable development of the department, stressed the need for modernization of teaching and methodological support of educational disciplines. In his speech, he paid a lot of attention to the issue of the importance of conducting vocational guidance work among schoolchildren. [5, 84].

The results of the campaign in 2018 showed positive changes - compared with 2017, the numbers have almost doubled. 20 Bachelor's entrants (12 in 2017), Master's level - 37 (22) and Doctor of Philosophy 10 (4). There was a renewal of the teaching staff. Nessen I., Parkhomenko N., Adrianova O., Tatievskaya I., Revenok N.N., Shman S., Goncharova O. came to the department to teach and began teaching practice, Krivets $Y$. joined the Department as a methodologist.

The analysis of state policy in the field of examination of cultural values [10] shows that the developers when drawing up legislation in the area of cultural practices conceptually relied on the experience of state institutions. The authority to conduct state expertise in the transfer of cultural property across the customs border is provided by a significant number of state institutions and organizations. There is no control over the presence in the designated organizations of professional experts as well as the requirements for their qualification have not been developed. There are also no requirements for the education of such specialists, which affects the development of the specialty of art expert adversely.

In the socio-cultural space of Ukraine, provision of services for the examination of cultural values and the training of specialists in this area is the latest phenomenon [9]. In general, the process of preparing experts in art critics at the National Academy of Culture and Arts Management can be divided into several stages. The initial phase (2001-2003) is characterized by the selection of the specialty of the expert and the creation of the corresponding department. A characteristic feature of this stage is the domination of attention to the preparation of a music expert, which is explained by the qualifications of the teaching staff, which had a musical education in the vast majority. At the second stage (from 2003 to 2010) the specialty of art expert was formed. The activity of the department was characterized by the stability of the teaching staff, which allowed to work out the thematic structure of educational 
disciplines, their teaching, and methodological support. Let us note the substantial influence of restoration techniques in the preparation of art experts, which is explained by the involvement into the education restorers along with art historians. There was a public recognition of the specialty of art expert, which was reflected in the increase in the number of applicants.

The reformist stage (2010-2017) is connected with the elimination of the department of art studies and expert activity, the introduction of a new qualification of a specialist in jewelry art and, subsequently, the return to the old skills of an expert in art criticism, the restoration and creation of the department of art criticism. This stage is characterized by negative consequences related to the instability of the teaching staff, a decrease in the level of teaching, methodological support, and the quality of education.

At the same time, there was a reappraisal of the experience gained and the formation of a competent list of academic disciplines for the preparation of experts that can be noted as a positive phenomenon. The teaching staff of the department has preserved the traditions of teaching the fundamental approaches of academic art in conjunction with practical skills in art criticism, appraisement of cultural values, and their restoration.

\section{תimepamypa}

1.Архів НАКККІМ, спр. 11/1-06, т. 1, протоколи засідання кафедри мистецтвознавства та експертної діяльності.

2.Архів НАКККІМ, спр. 11/1-06, т. 3, протоколи засідання кафедри мистецтвознавства та експертної діяльності.

3.Наказ ректора Національної академії керівних кадрів культури і мистецтв від 1 лютого 2012 р. № 83-к.

4.Архів НАКККІМ, справа 11/1-06, т. 4, протоколи засідання кафедри мистецтвознавства та експертної діяльності.

5.Архів НАКККІМ, справа 11/1-06, т. 5, протоколи засідання кафедри мистецтвознавчої експертизи.

6.Третій благодійний аукціон молодих митців «АРT A». URL: https://www.dolesko.com/Tretiij-blagodiijnij-aukciion-molodihmistciiv-ART-A.

7.Наказ Ректора Національної академії керівних кадрів культури і мистецтв від 27 серпня 2015 р. № $132-$-о.

8.Музеї та реставрація у контексті збереження культурної спадщини: актуальні виклики сучасності: Збірник наукових праць міжнародної науково-практичної конференції / під заг. ред.. В.Чернеця. Київ: Міленіум, $2016 ; 2017 ; 2018$.

9.Карпов В. Державна політика у сфері надання послуг з експертизи культурних цінностей // Вісник Національної академії керівних кадрів культури і мистецтва: наук. журнал. К.: Міленіум, 2017. № 2. С.19 - 26.

10. Карпов В.В. Імпортно-експортні операції на ринку культурних цінностей // Вісник Національної академії керівних кадрів культури і мистецтва: наук. журнал. К.: Міленіум, 2017. № 3. С. 12 - 16.

\section{References} Ukrainian]

1. Archive NAKKKIM, sp. 11 / 1-06, vol. 1, minutes of the session of the Department of Art Study and Expert Activity [in Ukrainian].

2. Archive NAKKKIM, sp. 11 / 1-06, vol.3, minutes of the session of the Department of Art Study and Expert Activity [in

3. Order of the Rector of the National Academy of Cultural and Arts Management from February 1, 2012 No. 83-k [in Ukrainian]. Ukrainian]

4. Archive NAKKKIM, case $11 / 1-06$, v. 4, minutes of the session of the Department of Art Study and Expert Activity [in

5. Archive NAKKKIM, case 11 / 1-06, t. 5, minutes of the session of the department of art examination expertise [in Ukrainian].

6. The third charity auction of young artists "ART A". URL: https://www.dolesko.com/Tretiij-blagodiijnij-aukciion-molodih-mistciivART-A. [in Ukrainian]. Ukrainian].

7. Order of the Rector of the National Academy of Cultural and Arts Management from August 27, 2015, No. 132-o [in

8. Museums and restoration in the context of preserving the cultural heritage: current challenges of the present: Collection of scientific works of the international scientific-practical conference / under the constituencies. ed .. V.Cernets. Kyiv: Millennium, 2016; 2017; 2018 [in Ukrainian].

9. Karpov, V. (2017). State policy in the field of rendering services for the examination of cultural values. Bulletin of the National Academy of Leaders of Culture and Arts: Sciences. magazine. K .: Millennium, 2, 19 - 26 [in Ukrainian].

10. Karpov, V.V. (2017). Import-Export Operations on the Market of Cultural Values. Bulletin of the National Academy of Directors of Culture and Arts: Sciences. magazine. K .: Millennium, 3, 12-16 [in Ukrainian]. 